\title{
THE IMPACT OF WOMEN'S TRAVELS ON MILITARY IMAGERY IN THE JULIO-CLAUDIAN PERIOD
}

\section{FouberT}

Anecdotes in the literary sources on the adventures of Agrippina Maior in Germania or of Julia Maior in Asia Minor clearly demonstrate that it was considered customary for a wife to travel through the provinces and join her husband during his military or diplomatic campaigns. At the same time, however, a woman was supposed to avoid the military, since this belonged to the public sphere, a domain which was traditionally reserved for men. During the Julio-Claudian period and thereafter, the tension between daily practice and ideal female behaviour played an important role in debates on social norms. The topic of women's travels in particular exposes aspects of the dominant ideologies with regard to female conduct and uncovers some of the mechanisms at work in the representation of Roman women. This contribution focuses on the correlation between the physical presence of imperial women in the provinces and their representation in literary and non-literary sources. The emphasis will lie on the western provinces, as we are better documented on women's travelling activities in these regions.

\section{UpPeR-Class Women En Route: Practice ANd Controversy}

The practice of women's travelling seems to have evolved from the extraordinary circumstances brought forth by a period of civil war in the first century вс. ${ }^{1}$ The earliest examples of travelling women that are extensively described by the ancient writers refer to wives following their husbands during flights out of Rome or exile. ${ }^{2}$ By the end of the century,

${ }^{1}$ The origin of women's travelling constitutes an important lacuna in modern scholarship as an in-depth study on the subject is missing. Scholarship is still largely confined to A.J. Marshall, 'Tacitus and the governor's lady. A note on Annals iii.33-4', Greece \& Rome 22 (1975a), and A.J. Marshall, 'Roman women and the provinces', Ancient Society 6 (1975b), which, though indispensable, merely scratches the surface of the subject.

${ }_{2}$ E.g. Appianus, Bellum civile 4.40; Valerius Maximus 6.7.3; Plutarch, Pompeius 74. 
the practice of wives accompanying their husbands abroad during military or diplomatic campaigns seems to have become common, with the example of Octavia who spent a considerable time with Antony in Athens as the best-known illustration of this development. ${ }^{3}$ It was similarly common practice for women of the Julio-Claudian family to accompany their husbands. Livia, for instance, is said to have joined Augustus during his travels in the eastern and western provinces, of which her presence in Gaul is the only specified attestation. ${ }^{4}$ Julia Maior followed her husband Agrippa during his campaign in Asia Minor, though the journey turned out to be not without peril. Julia almost drowned in the Scamander near Ilium on a night of heavy storms. ${ }^{5}$ During Agrippa's campaign she may have given birth to Agrippina Maior and perhaps also to Julia Minor. ${ }^{6}$ Several other imperial children were born in the provinces as well: Antonia Minor gave birth to Claudius in Lugdunum, Julia Maior delivered a child fathered by Tiberius in Aquileia, and Agrippina Maior gave birth to Agrippina Minor and Livilla while travelling with Germanicus. ${ }^{7}$ Near the end of the period under discussion, Statilia Messalina accompanied Nero during his voyage to Greece. ${ }^{8}$

Regardless of the fact that travelling women had become a common feature of Roman social life, the practice remained subject of male concern and public debate. The most illustrative example of the existing controversy occurs in Tacitus' description of Aulus Caecina Severus' intervention during a senatorial debate in $\mathrm{AD} 21 .{ }^{9}$ During a discussion on the question who should be the next governor of Africa, Caecina raised the issue of the presence of governors' wives in the provinces, which he saw as an insurmountable problem. In Caecina's view, women obstructed the execution of military campaigns, encouraged corrupt behaviour in men,

3 Plutarch, Marcus Antonius 33.

4 Tacitus, Annales 3.34.6; Seneca, De clementia 1.9.

5 FgrHist 90 F134. Cf. E. Fantham, Julia Augusti. The Emperor's Daughter (LondonNew York 2006), 66.

6 The exact birth-dates of Julia Minor and Agrippina Maior are unknown and have to be deduced from their marriages and the known birth-dates of their brothers. Cf. J.-M. Roddaz, Marcus Agrippa (Rome 1984), 448; Fantham 2006, op. cit. (n. 5), 59, 108.

7 Antonia Minor: Suetonius, Claudius 2.1; Seneca, Apocolocyntosis 6; Julia Maior: Suetonius, Tiberius 7.3; Agrippina Maior: Tacitus, Annales 2.54.1; 2.57.4; 2.75.1.

8 Acta Fratrum Arvalium (ed. Henzen), 84.

9 Tacitus, Annales 3.32-35. The debate has been studied in Marshall 1975a, op. cit. (n. 1) and A.A. Barrett, 'Aulus Caecina Severus and the military woman', Historia 54 (2005), 301-314 with the latter focusing on the underlying motives of Caecina's intervention through a study of his career. 
and were inclined to intrigue. ${ }^{10}$ The objections of Caecina, as articulated by Tacitus, seem to have been a prevailing view. Other authors such as Martial and Juvenal, near-contemporaries of Tacitus, voice similar sentiments in their descriptions of women's behaviour in the provinces. Both authors describe the wives of Roman officials staying in the provinces as greedy, corrupt and promiscuous. ${ }^{11}$ In modern research, a passage in Suetonius' Life of Augustus has sometimes been cited as an example of the anxiety felt by men about travelling women and their presence in the provinces. ${ }^{12}$ According to Suetonius, Augustus imposed renewed discipline by limiting the contact between officials and their wives during campaigns to brief winter visits. The author's phrasing, however, does not permit to interpret this regulation as an Augustan prohibition for women to travel. It does indicate, on the other hand, how Augustus felt that continuous contact between husbands and wives could distract the official in question from his duty-or at least that it was perceived as such by Suetonius.

Clearly, there seems to have been a tension between daily practice and general perception in this respect. In order to fully understand the literary and non-literary images discussed below which, as I see it, were fuelled by the presence of Julio-Claudian women abroad, one needs to be aware of the ideological discourses that played a role in the Romans' conception of female conduct, more specifically in the perception of the behaviour of upper-class women faced with a voyage to or stay in the provinces.

\section{Dealing with Ideological \\ Frontiers: Public versus Private}

As stated, in $21 \mathrm{AD}$ Caecina raised the issue of women's presence in the provinces during a senatorial debate. In Tacitus' account, the senator

\footnotetext{
10 Tacitus, Annales 3.33.

11 E.g. Juvenal, Satirae 6.398-412; 8.127-131; Martial, Epigrammata 2.56.

12 Suetonius, Augustus 24: Ne legatorum quidem cuiquam, nisi gravitate hibernisque demum mensibus, permisit uxorem intervisere (It was with great reluctance that he allowed even his generals to visit their wives, and then only in the winter season). Cf. Marshall 1975b, op. cit. (n. 1). On this passage and its various interpretations, see A.A. Barrett, 'Augustus and the governors' wives', Rheinisches Museum 149 (2006). Note that the translations used in this contribution are taken from the Loeb Classical Library editions. Translations from Tacitus' Annales are taken from A.J. Woodman, Tacitus. The Annals (Indianapolis 2004).
} 
criticized the practice of his day and the behaviour of his female contemporaries, while at the same time presenting himself and his wife as paradigms of exemplary behaviour:

Inter quae Severus Caecina censuit ne quem magistratum cui provincia obvenisset uxor comitaretur, multum ante repetito concordem sibi coniugem et sex partus enixam, seque quae in publicum statueret domi servavisse, cohibita intra Italiam, quamquam ipse pluris per provincias quadraginta stipendia explevisset.

(Tacitus, Annales 3.33)

It was in the midst of all this that Severus Caecina proposed that no magistrate to whose lot a province had fallen should be accompanied there by his wife (he had previously retracted at some length his own spouse's harmony with himself and her six childbirths and the fact that what he was establishing for the public good he had already observed at home, having restricted her to within Italy although he himself had fulfilled forty years' service across several provinces).

In Tacitus' version of Caecina's speech, the perceived opposition between the public and the private sphere is made explicit as an ideological concern. ${ }^{13}$ Caecina is positioned as a public figure, commendable for his years of service, while his wife is acknowledged for her role in the domus. She looked after the concordia between husband and wife and gave birth to six children. Both deeds contributed to what the Romans conceived of as ideal female behaviour. ${ }^{14}$ In Caecina's view, women's travels to the provinces, which implied leaving behind the domus and stepping into the public sphere, a domain traditionally seen as belonging to men, ruptured social order.

A similar ideological discourse appears in the consolatio which Seneca wrote to his mother from exile in $41 \mathrm{AD}$. In this text, he draws his mother's attention to her sister, a paragon of virtue and the ideal person to turn to for consolation. As the wife of Gaius Galerius, Seneca's aunt had spent sixteen years in Egypt, where her husband was governor. ${ }^{15}$ Seneca admires her because she never became the source or the subject of provincial gossip. In fact, she was never seen in public, but confined herself to the domus. Furthermore, she did not involve herself with her

${ }^{13}$ For a discussion on whether Tacitus' rendering of the debate should be considered fact or fiction, see F. Santoro L'Hoir, 'Tacitus and women's usurpation of power', Classical World 88 (1994), 12-17.

${ }^{14}$ On the impact of the ideal of female behaviour on the representation of Roman women, see L. Foubert, Women Going Public. Ideals and Conflicts in the Representation of Julio-Claudian Women (Nijmegen 2010, unpublished dissertation).

15 Seneca, Consolatio ad Helviam 19.6. 
husband's affairs, never seeking favours for herself or others. Seneca's aunt, so the author seems to suggest, deferred to the separation of the public and the private sphere and the traditional roles attributed to men and women.

The perceived tension between the public and the private sphere, as well as the Roman notion of the ideal of female conduct, played an important role in the representation of Julio-Claudian women. Their importance for the dynastic policy of the Julio-Claudian emperors provided them with an-according to Roman view-unprecedented public position and a high amount of visibility. ${ }^{16}$ The act of travelling shook up the perceived ideological boundaries between the public/private dichotomy. On the one hand, imperial women in a way abandoned their Roman domus, while at the same time associating themselves with the public and military domain. On the other hand, however, accompanying their husbands abroad seemed to have become an extension of their wifely duties. This is illustrated by Tacitus' rendering of the words of Drusus, which constituted the closure of the debate started by Caecina:

Addidit pauca Drusus de matrimonio suo; nam principibus adeunda saepius longinqua imperii. Quoties divum Augustum in Occidentem atque Orientem meavisse comite Livia! Se quoque in Illyricum profectum et, si ita conducat, alias ad gentis iturum, haud semper aequo animo si ab uxore carissima et tot communium liberorum parente divelleretur. (Tacitus, Annales 3.34)

Drusus added a few words about his own marriage: principes were often required to visit distant parts of the empire: how many times had Divine Augustus made expeditions to West and East with Livia as companion! He himself too had set off for Illyricum and, if it proved advantageous, would go to other nations, but always with a heavy heart if he were wrenched from his dearest wife, the parent of their numerous mutual children.

Taking the marital pair Augustus and Livia as an exemplum, Drusus' words suggest that standing alongside her husband was an intrinsic part of being an imperial woman. By following him, a woman did not cease to be a wife or mother, which formed her most important domestic roles. In fact, Tacitus' characterization of Agrippina Maior, which will be discussed next, indicates that the presence of a wife during her husband's travels led to the creation of a second (travelling) domus.

\footnotetext{
${ }^{16}$ For a study on the impact of the notions 'public' and 'private' on the representation of Julio-Claudian women, see Foubert 2010, op. cit. (n. 14), esp. chapter 2.
} 


\section{The Impact of Women's Travel on Tacitus' duX femina Model}

Let us now turn to some concrete examples of the impact of women's travels and their presence abroad on their representation, starting with the literary portrayals by ancient authors. The presence of upper-class women in the provinces is closely connected to the rhetorical stereotype of the dux femina, a common feature in the literary sources from the first century вс onwards. A dux femina can be defined as an upperclass woman "who acts as a dux or who attempts to exercise power". ${ }^{17}$ The stereotype always contains a reference to the military sphere, either through the appearance or dress of the woman in question, her deeds or behaviour, or the vocabulary used by the ancient author in his description. The preoccupation of ancient authors with transgressive military behaviour by women seems to have increased as the practice of travelling women became more common. ${ }^{18}$ Though the attested transgressions differ in nature, they all seem to have the same ideological discourse at their core: namely the conception that the presence of women in the provinces and their proximity to military affairs turns them into usurpers of masculine power, thus dissolving the separation of the public and the private sphere, which in its turn leads to general disorder and corruption.

Literary authors present the carrying of arms as the clearest manifestation of a woman's craving for power. A well-known example of this is the portrayal of Mark Antony's wife Fulvia in the works of Cicero, Plutarch and Cassius Dio. ${ }^{19}$ According to these authors, Fulvia was actively involved in military campaigns, addressing the troops and organising councils of war. She is even described as carrying a sword, which served as a visual marker of her status as a dux femina. ${ }^{20} \mathrm{~A}$ Julio-Claudian parallel to Fulvia's literary portrait is Suetonius' description of Caligula's wife Caesonia. The author states that Caesonia often accompanied the emperor when he met with his soldiers, riding by his side and wearing a cloak, helmet and shield. ${ }^{21}$ Of course, in these as well as in other cases, the literary characterization of women often contributed to the characterization of the husbands. Though the ancient authors do not make the notion

\footnotetext{
17 Santoro L'Hoir 1994, op. cit. (n. 13), 5.

18 On this subject, see Santoro L'Hoir 1994, op. cit. (n. 13).

19 Esp. Cicero, Phillippica 5.22; 13.18; Plutarch, Marcus Antonius 10.3; Cassius Dio 45.12-13.

20 Cassius Dio 48.10.3-4.

21 Suetonius, Caligula 25.
} 
of female travelling explicit as such, Fulvia and Caesonia are clearly dissociated from the domus. Their intrusion in the public sphere, both by being in the presence of soldiers and by dressing like one, turned them into a negative example of ideal female conduct.

The ancient authors' use of the stereotype of the dux femina does not necessarily always lead to character assassination, though it does so in the cases of Fulvia and Caesonia. In Tacitus' literary portrayal of Agrippina Maior, for instance, one can detect an undertone of praise for her actions on the battlefield. Tacitus' Agrippina Maior is arguably one of his most complex characterisations, as the reader needs a large frame of reference to fully grasp the complexity of her persona. Complete understanding is perhaps not even possible. Her literary portrayal is partly constructed through comparison with the portraits of her allies, for example Germanicus, and of her adversaries, for example Tiberius or Plancina. Unlike in the examples of Fulvia and Caesonia, the notion of female travelling is omnipresent in Tacitus' description of Agrippina and often provides the background for Tacitus' deliberate parallels between Agrippina and others. ${ }^{22}$

It is well-known that Agrippina Maior accompanied her husband Germanicus on several of his travels abroad. Both her presence in the West during Germanicus' military campaign in Germania in 14 AD and their journey to the East in $18 \mathrm{AD}$ are amply documented. Tacitus' description of Agrippina's stay in Germania presents her as a woman who travelled a long way to be with her husband and who followed military activities from up close. One example of her proximity to military affairs is her role in bringing down the mutiny which broke out among the soldiers after Augustus' death. ${ }^{23}$ Whereas other resources seemed to have failed, the public spectacle of a fleeing Agrippina and her infant son Caligula, together with a throng of crying upper-class women, wives of Germanicus' friends, evoked a sense of shame among the soldiers, thus bringing the uprising to an end. A second example of Agrippina's involvement in military life illustrates more clearly how Tacitus applied the stereotype of the dux femina in his literary characterization. ${ }^{24}$ When Germanicus and his army wanted to return to their camp after a military action, a rumour

${ }^{22}$ On Tacitus' technique of parallelling female lives, see L. Foubert, 'Literary constructions of female identities. The parallel lives of Julio-Claudian women in Tacitus' Annals, in C. Deroux (ed.), Studies in Latin Literature and Roman History, vol. 15 (Brussels 2010), 344-365.

23 Tacitus, Annales 1.40-41.

24 Tacitus, Annales 1.69. 
had spread among the remaining soldiers that they had been trapped on one side of the Rhine and that German warriors were planning an attack. Only the intervention of Agrippina prevented the panicking soldiers from demolishing the Rhine bridge at Vetera, which would have entrapped Germanicus and the retreating soldiers. Tacitus states:

Sed femina ingens animi munia ducis per eos dies induit, militibusque, ut quis inops aut saucius, vestem et fomenta dilargita est. Tradit C. Plinius, Germanicorum bellorum scriptor, stetisse apud principium pontis laudes et grates reversis legionibus habentem.

(Tacitus, Annales 1.69)

As it was, a femina of mighty spirit assumed during those days the responsibilities of a $d u x$ and distributed clothing and dressings to the soldiers according to each man's need or injuries. C. Plinius, the writer of the Germanic wars, transmits that she stood at the head of the bridge, extending praise and gratitude to the returning legions.

The authorial voice, by choice of vocabulary, clearly depicts Agrippina as a dux femina. Nevertheless, when one compares this passage with Tacitus' description of German women in Germania, which predates the Annales, the suggestion can be made that it was not the author's intention to paint a negative picture of Agrippina, but rather to praise her for the way she handled the crisis. It is well-known that in several instances Tacitus' attention was drawn to the conduct of German women, which he often considered opposite to contemporary Roman women and for which they deserved praise. In his view, German women were chaste and committed to their children and husband.$^{25}$ In fact, Tacitus claims that the exemplary behaviour of these women strengthened the bravery of their husbands on the battlefield. He believed that German women were present during military encounters, encouraging and praising their fighting husbands, after which they took care of the wounded and offered food to the warriors. ${ }^{26}$ The similarities between the author's view on German women and the description of Agrippina's conduct at the Rhine bridge are striking. Like the German women, Agrippina acted out of loyalty towards her husband. She did not gird on a sword, of which enough examples existed in Roman literature. Agrippina Maior's behaviour can be considered as that of a duxfemina, but in doing so she did not neglect her domestic roles. I would like to offer the hypothesis that the image of Agrippina as a 'travelling wife' and the location of her actions inspired

25 Tacitus, Germania 18-20.

${ }^{26}$ Tacitus Germania 7-8. Cf. J.B. Rives, Tacitus/ Germania (Oxford 1999), pp. 152153 . 
the author in his creative process: her presence in the Rhine region may have suggested to Tacitus a comparison with the German women.

The fact that Agrippina's role as a dux femina carries a positive connotation also derives from the parallel which Tacitus created between her and Plancina, the wife of Gnaeus Calpurnius Piso. Plancina resembles Agrippina in many aspects. ${ }^{27}$ She too was a member of the upper-class, and travelled abroad with her husband during his campaigns where she came into contact with the military sphere. However, in Tacitus' narrative, Plancina turned out to be a different sort of dux femina. Considering her behaviour during Piso's governorship of Asia, the author states:

Nec Plancina se intra decora feminis tenebat, sed exercitio equitum, decursibus cohortium interesse, in Agrippinam, in Germanicum contumelias iacere, quibusdam etiam bonorum militum ad mala obsequia promptis, quod haud invito imperatore ea fieri occultus rumor incedebat.

(Tacitus, Annales 2.55)

Nor did Plancina keep herself within female proprieties but participated in cavalry exercises and the marches-past of cohorts, and hurled insults at Agrippina and Germanicus-some even of the good soldiers being ready for wicked compliance with her, because there had spread a concealed rumor that such developments were not contrary to the commander's will.

Here, Tacitus openly criticizes Plancina's unwomanly behaviour and its corruptive effect on the people surrounding her. The contrast with the figure of Agrippina, whose actions were presented as an extension of her domestic roles, is obvious.

For the sake of completeness, I should call attention to a speech which Tacitus attributes to Tiberius in reaction to Agrippina's intervention on the bridge at Vetera. In this speech, the emperor complained about her behaviour during Germanicus' campaign. Recalling the incident, Tacitus states:

Id Tiberii animum altius penetravit: non enim simplicis eas curas, nec adversus externos studia militum quaeri. Nihil relictum imperatoribus, ubi femina manipulos intervisat, signa adeat, largitionem temptet, tamquam parum ambitiose filium ducis gregali habitu circumferat Caesaremque Caligulam appellari velit. Potiorem iam apud exercitus Agrippinam quam legatos, quam duces; conpressam a muliere seditionem, cui nomen principis obsistere non quiverit.

(Tacitus, Annales 1.69)

27 On Tacitus' parallel between Agrippina Maior and Plancina, see also Foubert 2010, op. cit. (n. 22). 
That (i.e. the incident on the bridge) made an unusually deep penetration into Tiberius' mind: it was not the case that her concerns were straightforward, he reflected, nor was it with the aim of opposing foreigners that she was seeking the soldiers' affections; nothing was left for commanders when a female visited the maniples, inspected the standards, experimented with lavishness - as though she did too little canvassing when she carried around the leader's son in a trooper's dress and wanted him called Caesar Caligula! Already Agrippina was more influential with the armies than legates, than leaders: the woman had suppressed a mutiny which the princeps's name had been unable to stop.

At first glance, this passage presents Agrippina as a negatively described dux femina, taking an opposite direction from Tacitus' earlier words. However, since the speech is delivered by one of Agrippina's adversaries, an emperor whose depraved character is elaborated upon in the Annales, the picture becomes ambiguous. At the same time, Tiberius' words are highly ironic, since they constitute a portent of Plancina's behaviour, who, together with her husband, was commissioned by that very emperor and his mother to make the lives of Germanicus and Agrippina difficult, at least according to Tacitus. ${ }^{28}$

\section{Female Portraits on Military Objects}

A final part of this contribution will examine the impact of women's travel on non-literary images. Over the years, utensils and other objects that can be attributed to a military context have been found containing depictions of female members of the Julio-Claudian family. Even though the appearance of female portraits on military objects concerns isolated cases, often difficult to identify, it might still indicate a broader iconographical trend. With the examples discussed below, I present the possibility that the presence of women in the provinces inspired the creative process of the image-makers, who took advantage of the fact that the user or recipient of these objects was familiar with the depicted woman's persona. $^{29}$

28 Tacitus, Annales 2.43 .

${ }^{29}$ Unfortunately, there is no general study on the appearance of portraits of imperial men or women on military or other utensils. In the present contribution, I will limit myself to objects found in the western provinces, since these are published most extensively. It would, however, be worthwhile to examine objects found in the eastern provinces as well and compare them to the travel activities of imperial women in these regions. The current state of research does not yet allow such a comparison. 
As stated above, the travelling activities of Agrippina Maior are widely documented in the literary sources. When considering her non-literary representation, various occasions show a reflection of her reputation as a 'military wife' in the visual language used by the image-makers. The portrait of Agrippina Maior, for instance, appears on glass phalerae from Caligula's reign. Phalerae were given as a reward to deserving soldiers and many of them were found in the German regions. ${ }^{30}$ It is unclear who decided on the subject for these medallions, but obviously the portrait of Agrippina was regarded to have a certain symbolic value and to be appreciated by the recipient of the gift. Her presence in the vicinity of the troops stationed in Germania and her actions on the bridge at Vetera may very well have contributed to her popularity.

The portrayal of Agrippina Maior on the so-called Gemma Claudia should be seen in the same light. ${ }^{31}$ Often interpreted as a wedding gift to Claudius and Agrippina Minor, the cameo shows the overlapping busts of the emperor and his new wife facing right and the busts of Germanicus and Agrippina Maior facing left. The entire composition rests on a collection of captured armour, referring to the spoils of victory of Claudius' military campaign in Britain and Germanicus' campaign in Germania. ${ }^{32}$ Claudius wears an oak crown and the aegis of Jupiter, while Germanicus wears a laurel wreath and a military paludamentum. Agrippina Maior's portrait refers to the military as well, for she wears a laurel wreath, like her husband, combined with a crested helmet. These manly attributes astonish Wood, who states that "the most obvious association is with Minerva, but here as in so many other cases, the identification of the virgin goddess

30 Other surviving phalerae can be divided in three sets: a Tiberian set with images of Tiberius with Drusus and Germanicus, a Caligulan set with portraits of Agrippina Maior, Caligula and Germanicus, and thirdly a Claudian set with images of Claudius and his children. The most extensive treatment of these phalerae is D. Boschung, 'Römische Glasphalerae mit Porträtbüsten', Bonner Jahrbücher 187 (1987). See also, F. Drexel, 'Ein Bildnis der älteren Agrippina', in C. Albizzati (ed.), Antike Plastik. Walther Amelung zum sechzigsten Geburtstag (Berlin-Leipzig 1928), 67-72; J. Stäcker, Princeps und miles. Studien zum Bindungs- und Nahverhältnis von Kaiser und Soldat im 1. und 2. Jahrhundert n. Chr. (Hildesheim 2003), 153-169.

31 W.-R. Megow, Kameen von Augustus bis Alexander Severus (Berlin 1987), no. A81; T. Mikocki, Sub specie dea. Les impératrices et princesses romaines assimilées à des déesses: étude iconologique (Rome 1995), no. 214; A. Alexandridis, Die Frauen des römischen Kaiserhauses. Eine Untersuchung ihrer bildlichen Darstellung von Livia bis Iulia Domna (Mainz am Rhein 2004), nos. 74, 123.

32 S. Wood, Imperial Women. A Study in Public Images, 40 BC-AD 68 (Leiden 1999), 306. 
with the mother of nine children makes an awkward fit." 33 Wood does not find a conclusive context for an association with Minerva because she focuses on the aspect of the virginity of the goddess. However, the imagery bears above all a military connotation and, therefore, it seems more fitting to focus on the martial aspect of the attributes. The depiction of Agrippina with military attributes on the Gemma Claudia agrees with her military background and presents her as a worthy consort of Germanicus.

Two other military objects seem to depict Julio-Claudian women as well, but in these cases identification is more difficult to make. The first is a drinking cup found in Vetera and contains the signature of Chrysippus. ${ }^{34}$ On this cup, the association with the military is made through depictions of various wreaths together with refigurations of Victoria and Minerva. The cup contains images of 4 columns of which two show on top busts of members of the imperial family, possibly Augustus and Livia. ${ }^{35}$ The second example is a bronze scabbard from the Augustan period, found in Bonn, showing three figures, two male and one female. ${ }^{36}$ The male figures both wear a breastplate and a military cloak. In their midst stands a female figure with her hair in the so-called nodus hairdo. Based on the figures' hairstyles, two suggestions for identification have been made. According to a first hypothesis, the threesome represents Julia Maior with her sons Gaius and Lucius Caesar. ${ }^{37}$ In this view, the image should be read as a reference to Augustus' dynastic policy. A second hypothesis identifies the three figures as Livia with her sons Tiberius and Drusus and sees the scabbard as a commemoration of the Roman military campaign in the Alps in 15 BC. ${ }^{38}$ Both Livia and Julia Maior have been attested travelling with their husbands during military and diplomatic campaigns. As mentioned above, the sources state that Livia in par-

33 Wood 1999, op. cit. (n. 32), 307.

34 LVR-Landesmuseum Bonn, inv. 22534, 1-1.

35 H. Lehner, 'Zwei Trinkgefässe aus Vetera', Bonner Jahrbücher 122 (1912), 430435; K. Galinsky, Augustan Culture. An Interpretive Introduction (Princeton 1996), 329; J. Komp, 'ACO-Becher', in 2000 Jahre Varusschlacht. Imperium (Stuttgart 2009), no. 7.2.

36 LVR-Landesmuseum Bonn, inv. 4320. Cf. A. Reis, 'Zierblechfragment einer Schwertscheide', in 2000 Jahre Varusschlacht. Imperium (Stuttgart 2009), no. 5.22.

37 E.g. P. Zanker, Augustus und die Macht der Bilder (Munich 1987), 221; E.R. Varner, Mutilation and Transformation. Damnatio memoriae and Roman Imperial Portraiture (Leiden 2004), 87. Cf. A. Reis 2009, op. cit. (n. 36).

38 E.g. B. Severy, Augustus and the Family at the Birth of the Roman Empire (New York-London 2003), 87. Cf. Reis 2009, op. cit. (n. 36). 
ticular spent some time in the western provinces. ${ }^{39} \mathrm{It}$ is, however, difficult to ascertain the relation between their travels and the imagery on these military objects.

Obviously, it is difficult to determine the exact origins of the development of a new visual language. In the West, depictions of women in a military context, with the exception of military divinities, do not appear before the Augustan period. ${ }^{40}$ One could imagine that artists sought a way to translate the extraordinary position of the Julio-Claudian women, leading perhaps to the choice for military elements. In some cases, such as the example of Agrippina Maior, the fame connected to the woman's presence in the provinces would have made that choice obvious.

Travelling became a common practice for female members of the JulioClaudian family. Even though the presence of women in the provinces seemed to have been received with controversy, in several instances it also appears that the notion of 'imperial wives en route' contributed to the public image of the imperial family. The presence of Julio-Claudian women alongside their husbands evoked an image of marital harmony and familial unity. The case of Agrippina Maior in particular shows that a woman's activities abroad could have a strong impact on her representation in literary as well as non-literary sources. The travels of Agrippina Maior resulted in the crossing of both geographical and ideological frontiers.

Nijmegen, December 2009

39 Tacitus, Annales 3.34.6.

40 A coin type minted by Mark Antony with a portrait of a winged Victoria has often been interpreted as a representation of his wife Fulvia ( $R P C$ 512-513). This identification, however, is highly uncertain. On the association of imperial women with so-called military deities, such as Minerva or Dea Roma, see L. Foubert 2010, op. cit. (n. 14), chapter 5 . 